\title{
The Mediating Effects of Job Satisfaction on Role Stressors and
}

\section{Affective Commitment}

\author{
Omer Farooq Malik (Corresponding author) \\ Department of Management Sciences \\ COMSATS Institute of Information Technology, Islamabad, Pakistan \\ Tel: 92-300-9199-678 E-mail: omer_farooq@comsats.edu.pk
}

Aamer Waheed

Department of Management Sciences

COMSATS Institute of Information Technology, Islamabad, Pakistan

E-mail: awaheed@comsats.edu.pk

Khalil-Ur-Rehman Malik

Department of Management Sciences

COMSATS Institute of Information Technology, Islamabad, Pakistan

E-mail: khalil_rehman@comsats.edu.pk

\begin{abstract}
The study aimed at exploring the mediating effects of job satisfaction on role stressors namely, role overload and role conflict as sources of stress, on one hand, and affective commitment, on the other. Using a self-administered questionnaire, 151 branch managers of private sector commercial banks in Pakistan were randomly selected and surveyed to examine the mediating role of job satisfaction. Results revealed that role overload and role conflict directly and negatively influence job satisfaction. It was also found that role overload and role conflict directly and negatively influence affective commitment. The causal steps method along with correlation tests revealed that job satisfaction partially mediated the effects of role overload and role conflict on affective commitment. Implications, limitations, and future lines of research are also discussed in the paper.
\end{abstract}

Keywords: Role overload, Role conflict, Affective commitment, Mediation, Pakistan

\section{Introduction}

Banks play a vital role in the economy of a country. Banks are primarily engaged in the business of accepting deposits from the savings-surplus units and investing/lending these funds in their own name to the savings-deficit units (Horne and Wachowicz, 1998). During a period of five years 2000-2005 the banking sector of Pakistan has been transformed into a much more swift and competitive industry. Due to the privatization of large public sector banks the banking industry is now characterized by customer focus, quality, convenience, innovation, and speed.

Branch manager being the administrative head is an important link between the branch office and the head office. Branch managers play a significant role in the smooth functioning of branch offices. However, the occupation is considered stressful because the job is often characterized by heavy workloads, several deadlines, time constraints, and high degree of customer contact. Severe job stress is dysfunctional in that it has been related to decreased job satisfaction and organizational commitment, and increased absenteeism and turnover (Kahn et al., 1964; Bedeian and Armenakis, 1981; Kemery et al., 1985; Schaubroeck et al., 1989).Yousef (2002b) results suggest that role conflict and role ambiguity as sources of stress are negatively associated with job satisfaction and various dimensions of organization commitment. His results further suggest that job satisfaction mediates the effects of role conflict and role ambiguity on affective and normative commitment. Therefore, it is important to understand the causes of job stress and the negative effects severe job stress may have on both employees and organizations. 


\subsection{Objectives of the Study}

The objectives of this study are two-fold:

1. To investigate the relationships between role stressors namely, role overload and role conflict, job satisfaction, and affective commitment.

2. To explore the mediating effects of job satisfaction on role overload and role conflict as causes of stress, on one hand, and affective commitment, on the other.

\section{Literature Review}

\subsection{Job Stress}

Stress in general differs from job stress as the latter is organizational in nature (Montgomery et al., 1996). Job stress is any characteristic of the workplace that causes threat to the individual (Larson, 2004). Job stress occurs when the individual doesn't have the skills and abilities to perform the job effectively, when he lacks in training or is not provided with necessary resources to perform his job, or when he is confronted with conflicting job demands (Jamal, 1990).

\subsection{Role}

Aziz (2004) describes an important aspect of organization whereby role is allocated to the individual which integrates him/her within the overall structure of the organization. It is through this role that an individual interacts and becomes a part of the system. Pareek (1993) describes role as a set of functions one performs in response to the expectations of the "significant others" and one's own expectations from that position.

\subsection{Role Stress}

The traditional theory of role stress asserts that job dissatisfaction, absenteeism, and turnover intentions are directly caused by role stressors (Kahn et al., 1964; Bedeian and Armenakis, 1981; Kemery et al., 1985). The attitudinal models of the turnover process contradict this view and suggest that organizational commitment mediates the relationship between job characteristics and several behavioral outcomes (Steers, 1977). However, the turnover models differ in that some assume job satisfaction to mediate the effects of job characteristics on organizational commitment (Steers and Mowday, 1981; Oliver and Brief, 1977; Farrel and Rusbult, 1981) while others consider job satisfaction and job characteristics to be independent determinants of organizational commitment (Morris and Sherman, 1981).

\subsection{Role Stressors}

Role stressors are conceptualized using three interrelated but distinct constructs: role conflict, role ambiguity, and role overload (Singh, 1998; Montgomery et al., 1996). According to Larson (2004) role conflict results from conflicting job demands such that compliance with one makes compliance with another difficult or impossible. Rizzo et al., (1970) define role conflict in terms of the dimensions of compatibility-incompatibility in the requirements of the role, where compatibility is judged relative to a set of standards which impinge upon role performance. Role ambiguity has been described as the situation where there is lack of clear expectations from the role or lack of feedback on performance (Aziz, 2004). Role overload can be classified into quantitative and qualitative overload (Fineman and Payne, 1981). Quantitative role overload is the conflict between organizational demands and the time given to the individual to meet those demands (Bacharach et al., 1991; Larson, 2004). Fineman and Payne describe qualitative role overload as work that exceeds an individual's skills, knowledge, and abilities. Role overload and role conflict tend to be used interchangeably in the literature when, in fact, they are correlated but separate concepts (Kahn et al., 1964; Parasuraman and Alluto, 1984; Schaubroeck et al., 1989; Coverman, 1989; Montgomery et al., 1996).

\subsection{Job Satisfaction}

Job satisfaction is defined as "an attitude that individuals have about their jobs. It results from their perception of their jobs and the degree to which there is a good fit between the individual and the organization" (Ivancevich et al., 1997, p.91). The attitudinal nature of job satisfaction implies that an individual would tend to stay with a satisfying job and quit a dissatisfying job (Spector, 1985). In research literature job satisfaction is closely associated with organizational commitment (Clugston, 2000; Meyer et al., 2002; Yousef, 2002a; Bateman and Strasser, 1984). Numerous researchers have found that job satisfaction mediates the influence of several other variables on organizational commitment (For example, William and Hazer, 1986; Mathieu and Hamel, 1989; Lok and Crawford, 2001; Yousef, 2002a). 


\subsection{Organizational Commitment}

The concept of organizational commitment has received increased attention in the research literature (Steers, 1977; Bateman and Strasser, 1984; Morrow; 1993). Porter et al., (1974) define organizational commitment as the relative strength of an individual's identification with and involvement in a particular organization. Allen and Meyer (1990) proposed a three-dimensional attitudinal construct of organizational commitment namely, affective, normative, and continuance commitment. According to Allen and Meyer affective commitment is an individual's emotional attachment to the organization. Normative commitment reflects individual's sense of moral obligation to remain with the organization. On the other hand, continuance commitment is based on the individual's recognition of costs associated with leaving the organization.

Affective commitment is considered more effective measure of organizational commitment since it indirectly influences the other two dimensions of organizational commitment (Boles et al., 2007) and is more consistent with the conceptual and operational definition of attitudes (Iverson and Buttigieg, 1999). Research also provides evidence that, there is high correlation between affective and normative commitment (Cohen, 1996; Meyer et al., 2002). Therefore, for this study we have focused on this aspect of commitment in Allen and Meyer's three-dimensional commitment model.

In research literature organizational commitment has been investigated from various perspectives. Organizational commitment has been analyzed as a dependent variable for antecedents such as job satisfaction, job involvement, demographic variables, role stressors (Allen and Meyer, 1990; Dixon et al., 2005; Lok and Crawford, 2001; Udo et al., 1997; Addae et al., 2008; Schaubroeck et al., 1989). Numerous studies have treated organizational commitment as a predictor of important outcomes such as turnover intentions, turnover, and absenteeism (Elangovan, 2001; Carmeli and Gefen, 2005; Meyer et al., 2004; Porter et al., 1974; Mathieu and Zajac, 1990; Lee, 1988; Falkenburg and Schyns, 2007). Apart from antecedent-consequence relationships organizational commitment has also been studied as a mediating variable by various researchers (For example, Suliman, 2002; Clugston, 2000; Tompson and Werner, 1997; Netemeyer et. al., 1995; Udo et al., 1997).

\subsection{Single Mediator Model}

Researchers in organizational behavior are placing increasing importance on single mediator models in which the effect of an antecedent is transmitted to a consequence through a mediator (James and Brett, 1984). Preacher and Hayes (2004) state that the simple relationship between $\mathrm{X}$ and $\mathrm{Y}$ is referred to as the total effect of $\mathrm{X}$ on $\mathrm{Y}$ denoted by c. However, when the relationship between $X$ and $Y$ is mediated by one variable $(M)$ the effect of $X$ on $\mathrm{Y}$ is referred to as the direct effect denoted by $\mathrm{c}^{\prime}$. The indirect effect of $\mathrm{X}$ on $\mathrm{Y}$ is defined as the product of $\mathrm{X} \rightarrow \mathrm{M}$ path (a) and the $\mathrm{M} \rightarrow \mathrm{Y}$ path (b), or ab (see Figure 1, Panel A and B).

Baron and Kenny (1986) causal steps method is widely used for mediation analysis in the management literature (For example, Yperen et al., 1999; Lok and Crawford, 2001; Vandewalle et al., 1995; Suliman, 2002).

The three regression equations for the single mediator model are as follows:

1) The dependent variable $(Y)$ is first regressed on the independent variable $(X)$. This step is assessed by estimating the following equation:

$$
\mathrm{Y}^{\prime}=\alpha_{1}+\mathrm{cX}+\mathrm{e}_{1}
$$

Equation (1)

(where $\alpha_{1}$ is the intercept coefficient and $\mathrm{e}_{1}$ is the error term)

The purpose of this first test is to establish that there is an effect to mediate. If $\mathrm{c}$ is not statistically significant in Equation (1), then the analysis for consistent mediation stops (Mackinnon, 2008).

2) The mediating variable (M) is regressed on the independent variable (X). This step is assessed by estimating the following equation:

$$
\mathrm{M}^{\prime}=\alpha_{2}+\mathrm{aX}+\mathrm{e}_{2}
$$

(where $\alpha_{2}$ is the intercept coefficient and $\mathrm{e}_{2}$ is the error term)

3) The dependent variable $(\mathrm{Y})$ is simultaneously regressed on the independent variable $(\mathrm{X})$ and the mediating variable (M). This step is assessed by estimating the following equation:

$$
\mathrm{Y}^{\prime \prime}=\alpha_{3}+\mathrm{c}^{\prime} \mathrm{X}+\mathrm{bM}+\mathrm{e}_{3}
$$

(where $\alpha_{3}$ is the intercept coefficient and $e_{3}$ is the error term) 
According to Preacher and Hayes (2004) variable M is considered a mediator if it fulfills the following three conditions:

1) $\mathrm{X}$ significantly predicts $\mathrm{Y}$ i.e. $(\mathrm{c} \neq 0$ in Equation 1$)$;

2) $\mathrm{X}$ significantly predicts $\mathrm{M}$ i.e. $(\mathrm{a} \neq 0$ in Equation 2$)$; and

3) $\mathrm{M}$ significantly predicts $\mathrm{Y}$ controlling for $\mathrm{X}$ i.e. $(\mathrm{b} \neq 0$ in Equation 3$)$.

\subsection{Complete and Partial Mediation}

There is evidence for complete mediation when the effect of $\mathrm{X}$ on $\mathrm{Y}$ with the inclusion of $\mathrm{M}$ is insignificant. In this case, $c^{\prime}$ or the direct effect must not be significantly different from zero. However, when the effect of $\mathrm{X}$ on $\mathrm{Y}$ with the inclusion of $\mathrm{M}$ is reduced in magnitude, but remains significant, there is evidence for partial mediation (Preacher and Hayes, 2004). The partial mediation case allows $c^{\prime}$ to be significant and makes sense that partial mediation is perhaps more realistic than complete mediation in social sciences research because of the many causes of behavior (Baron and Kenny, 1986).

\section{Theoretical Framework and Methodology}

\subsection{Theoretical Framework}

The schematic diagram shows two independent variables, namely role overload and role conflict as sources of stress, job satisfaction as a mediating variable, and affective commitment as dependent variable (see Figure 2).

\subsection{Methodology}

This section discusses the data collection method, sample, and the instruments used to measure the variables of the study.

\subsubsection{Data Collection Method}

A personally administered questionnaire was used to collect the data. This type of data collection method was used as it was less expensive and facilitated in collecting the completed responses within a short period of time.

\subsubsection{Sample}

A pilot study was conducted before distributing the questionnaire to test the validity of the measures. The sample of the study consisted of 200 branch managers of private sector commercial banks in two Pakistani cities Rawalpindi and Islamabad. A total of 200 questionnaires were distributed. 158 questionnaires were returned, resulting in a response rate of $79 \%$. Of the returned questionnaires, 151 were suitable for data analysis.

Table 1 presents the main characteristics of the sample. Of the subjects, about $(93 \%)$ are male and $(7 \%)$ are female. Of the subjects, about (14\%) have 14 years bachelor degree, $(83 \%)$ have 16 years bachelor/master degree, and $(3 \%)$ have 18 years master degree. Of the subjects, $(47 \%)$ have been working as branch manager for less than 5 years and $(53 \%)$ for 5 years or more.

\subsubsection{Measures}

Role overload was measured using two dimensions: quantitative overload and qualitative overload. These dimensions were measured using the Ivancevich and Matteson (1980) scale. This scale consists of six items. A five-point likert scale was used, ranging from 1 (strongly disagree) to 5 (strongly agree). Examples of the items included in this scale are: "I simply have more work to do than can be done in an ordinary day" and "I have insufficient training and/or experience to discharge my duties properly". The internal consistency (Cronbach's alpha) in this study for the quantitative sub-scale was .82 and for the qualitative sub-scale was .84 .

Role conflict was measured using the Rizzo et al., (1970) scale. This scale consists of eight items. A five-point likert scale was used, ranging from 1 (strongly disagree) to 5 (strongly agree). Examples of the items included in this scale are: "I have to do things that should be done differently" and "I receive an assignment without the manpower to complete it". The internal consistency (Cronbach's alpha) for the scale in this study was .85 .

Job satisfaction was measured using the shortened version of the Minnesota Satisfaction Questionnaire (Johnson and Weiss, 1971). This scale consists of twenty items and is considered a global measure of job satisfaction. A five-point likert scale was used, ranging from 1 (very dissatisfied) to 5 (very satisfied). Examples of the items included in this scale are: "The chance to do something that makes use of my abilities" and "My pay and the amount of work I do". The internal consistency (Cronbach's alpha) for the scale in this study was .79.

Affective commitment was measured using the (Porter et al., 1974; Modway et al., 1979) nine items scale. A five-point likert scale was used, ranging from 1 (strongly disagree) to 5 (strongly agree). Examples of the items included in this scale are: "I find that my values and the organization's values are very similar" and "I am proud 
to tell others that I am part of this organization". The internal consistency (Cronbach's alpha) for the scale in this study was .80 .

\section{Hypotheses}

This section discusses the hypotheses of the study.

\subsection{Hypothesis 1}

One could argue that those who perceived higher levels of role overload as source of stress would be less satisfied with the job. This argument has been supported by previous research (For example, Abdalla, 1991; Singh et al., 1994; Fox et al., 1993; Jones et al., 2007; Yousef, 2002b; Karsh et al., 2005). Therefore, it could be hypothesized that:

H1: Role overload is negatively associated with job satisfaction.

\subsection{Hypothesis 2}

One could argue that those who perceived higher levels of role conflict as source of stress would be less satisfied with the job. This argument has been supported by earlier research (For example, Yousef, 2002a; Bedeian and Armenakis, 1981; Behrman and Perrault, 1984; Singh, 1998; Schaubroeck et al., 1989; Ruyter et al., 2001; Karsh et al., 2005; Udo et al., 1997). Therefore, it could be hypothesized that:

$\mathrm{H} 2$ : Role conflict is negatively associated with job satisfaction.

\subsection{Hypothesis 3}

One could argue that those who perceived higher levels of role overload as source of stress would be less committed to the organization. This argument has been supported by previous research (For example, Singh et al., 1994; Jones et al., 2007; Stevens et al., 1978; Yousef, 2002b). Therefore, it could be hypothesized that:

H3: Role overload is negatively associated with affective commitment.

\subsection{Hypothesis 4}

One could argue that those who perceived higher levels of role conflict as source of stress would be less committed to the organization. This argument has been supported by previous research (For example, King and Sethi, 1997; Singh, 1998; Meyer et al., 2002; Addae et al., 2008). Therefore, it could be hypothesized that:

H4: Role conflict is negatively associated with affective commitment.

\subsection{Hypothesis 5}

Several researchers have reported a positive association between job satisfaction and affective commitment (For example, Jenkins and Thomlinson, 1992; Clugston, 2000; Meyer et al., 2002; Yousef, 2002a; Bateman and Strasser, 1984; Boles et al., 2007). Therefore, it could be hypothesized that:

H5: Job satisfaction is positively associated with affective commitment.

\subsection{Hypothesis 6}

One could argue that job satisfaction mediates the effect of role stressors on organizational commitment. This argument has been supported by previous research (For example, Steers and Mowday, 1981; Oliver and Brief, 1977; Farrel and Rusbult, 1981; Yousef, 2002a,b). Therefore, it could be hypothesized that:

H6a: Job satisfaction mediates the effect of role overload on affective commitment.

H6b: Job satisfaction mediates the effect of role conflict on affective commitment.

\section{Data Analysis}

SPSS version 16 was used to analyze the collected data. Frequencies and percentages were used to present the main characteristics of the sample. Maximum, minimum, means, standard deviations, and intercorrelations of the main variables were also calculated. Following the Baron and Kenny (1986) causal steps method simple and multiple linear regression was used for testing the mediating role of job satisfaction. In addition, bivariate and partial correlation tests were used to examine the mediating role of job satisfaction (Suliman, 2002). The significance of indirect effect was computed using the Sobel test.

\section{Results}

Table 2 presents the descriptive statistics of the main variables of the study. Results indicated that branch managers in the investigated banks perceive moderate levels of role overload $(\mathrm{M}=3.38)$ and role conflict $(\mathrm{M}=$ 
3.26) as sources of stress. Results also showed that they experience low levels of job satisfaction $(\mathrm{M}=2.62)$ and affective commitment $(\mathrm{M}=2.42)$.

Correlation results presented in Table 3 indicate that there was significant negative relationship between role overload and job satisfaction $(\mathrm{r}=-.417, \mathrm{p}<.01)$. In addition, there was significant negative relationship between role conflict and job satisfaction $(\mathrm{r}=-.410, \mathrm{p}<.01)$. A significant negative relationship between role overload and affective commitment $(\mathrm{r}=-.411, \mathrm{p}<.01)$ was found. In addition, a significant negative relationship was found between role conflict and affective commitment $(\mathrm{r}=-.366, \mathrm{p}<.01)$. There was a significant positive relationship between job satisfaction and affective commitment $(\mathrm{r}=.539, \mathrm{p}<.01)$.

The results indicate that role overload and role conflict as sources of stress are negatively associated with job satisfaction. This supports $\mathrm{H} 1$ and $\mathrm{H} 2$, which stated that role overload are role conflict are negatively associated with job satisfaction.

Results also indicate that role overload and role conflict as sources of stress are negatively associated with affective commitment. This supports $\mathrm{H} 3$ and $\mathrm{H} 4$, which stated that role overload and role conflict are negatively associated with affective commitment.

Further, results show that job satisfaction positively influences affective commitment. This supports H5, which stated that job satisfaction is positively associated with affective commitment. These results are in line with previous research findings (For example, Jenkins and Thomlinson, 1992; Clugston, 2000; Meyer et al., 2002; Yousef, 2002a; Bateman and Strasser, 1984; Boles et al., 2007).

\subsection{Results of the Mediated Regression Approach for JS (RO-AC)}

The results of the causal steps method for JS (RO-AC) are presented in Table 4. The beta value of RO-AC relationship in the first step was -.411 (the total effect). The inclusion of JS in the third step reduced this beta value to -.226 but remained significant (the direct effect). The indirect effect of $\mathrm{RO}$ on $\mathrm{AC}$ was equal to the product of $\mathrm{RO} \rightarrow \mathrm{JS}$ path and the JS $\rightarrow$ AC path i.e. (-.417) (.445) $=-.185$. Since the direct effect was significantly different from zero therefore, it was concluded that JS partially mediated the relationship between RO and AC (see Figure 3).

\subsection{Results of the Mediated Regression Approach for JS (RC-AC)}

The results of the causal steps method for JS (RC-AC) are presented in Table 5. The beta value of RC-AC relationship in the first step was -.366 (the total effect). The inclusion of JS in the third step reduced this beta value to -.175 but remained significant (the direct effect). The indirect effect of $\mathrm{RC}$ on $\mathrm{AC}$ was equal to the product of $\mathrm{RC} \rightarrow \mathrm{JS}$ path and the JS $\rightarrow$ AC path i.e. (-.410) (.467) $=-.191$. Since the direct effect was significantly different from zero therefore, it was concluded that JS partially mediated the relationship between RC and AC (see Figure 4).

\subsection{The Results of the Correlation Tests}

The results of the correlation tests are shown in Table 3.

\subsubsection{JS (RO-AC)}

The bivariate and partial correlation test results indicate that the correlation between $\mathrm{RO}$ and $\mathrm{AC}$ was $(\mathrm{r}=-.411$, $\mathrm{p}<.01)$. However, when JS was controlled, the correlation coefficient was reduced in magnitude $(r=-.244, p<.01)$ but remained statistically significant.

\subsubsection{JS (RC-AC)}

The bivariate and partial correlation test results indicate that the correlation between RC and AC is $(\mathrm{r}=-.366$, $\mathrm{p}<.01)$. However, when JS was controlled, the correlation coefficient was reduced in magnitude $(r=-.189, \mathrm{p}<.05)$ but remained statistically significant.

Hence, the findings of bivariate and partial correlation tests were in line with the results of the causal steps method with respect to the mediating role of job satisfaction. This supports H6a and H6b, which stated that job satisfaction mediates the influence of role overload and role conflict on affective commitment. These results are in line with previous research findings (For example, Steers and Mowday, 1981; Oliver and Brief, 1977; Farrel and Rusbult, 1981; Yousef, 2002a,b).

\subsection{Significance of the Indirect Effect}

The significance of the indirect effect was computed using the Sobel test (Baron and Kenny, 1986; Preacher and Hayes, 2004; Shrout and Bolger, 2002). It was found that the indirect effect of role overload on affective commitment via job satisfaction was significantly different from zero $(z=-4.10, p<.001)$. The indirect effect of 
role conflict on affective commitment via job satisfaction was also significantly different from zero $(\mathrm{z}=-4.13$, $\mathrm{p}<.001)$. This further supported our hypothesis that job satisfaction partially mediated the effect of role overload and role conflict on affective commitment and both indirect effects were significantly different from zero i.e. $\mathrm{ab}>0$.

\section{Discussion of Results}

The results that role overload and role conflict are negatively associated with job satisfaction suggest that those managers who experience high levels of role overload and role conflict as sources of stress are less satisfied with the job. This would have negative consequences for both employees and organizations. Yousef (2002b) findings also suggest that role stressors are negatively associated with job satisfaction among employees in various organizations in the United Arab Emirates. The results that role overload and role conflict are negatively associated with affective commitment suggest that those managers who perceive high levels of role overload and role conflict as sources of stress are less willing to remain in the organization. This would have negative consequences on the organization.

The results that job satisfaction is positively associated with affective commitment suggest that those managers who are happy with their jobs are more willing to remain in the organization. This positive relationship between job satisfaction and affective commitment would be of benefit for management in the sense that they should make every effort to improve job satisfaction for their managers to enhance their commitment to the organization (Yousef, 2002b; Meyer et al., 2002).

The results that job satisfaction mediates the effect of role overload and role conflict on affective commitment suggest that those managers who perceive high levels of role overload and role conflict are less satisfied with the job and consequently are less willing to remain in the organization. Both role overload and role conflict significantly effect affective commitment directly and indirectly via job satisfaction (Steers and Mowday, 1981; Oliver and Brief, 1977). Maintaining low perceptions of role overload and role conflict among managers would most likely result in low role stress. Low role stress in turn will have positive consequences on job satisfaction and affective commitment.

\section{Conclusion and Recommendations}

The major finding of this research is that role overload and role conflict as sources of stress negatively influence affective commitment directly and indirectly via job satisfaction. Low perceptions of role overload and role conflict would most likely result in low role stress and that in turn will have positive consequences for both employees and organizations. Branch managers' perception of role stress can be reduced by:

- $\quad$ Providing them training in areas like time management and stress management,

- Strengthening their competence on continuous basis to match the demanding nature of work,

- Ensuring adequate supply of skilled workforce at branch offices,

- Setting up realistic deadlines,

- Removing the insignificant aspects of their job, and

- Granting them some degree of autonomy in deciding what procedures to follow to accomplish a task.

\section{Limitations and Future Research}

First, the study investigated the effects of role stressors namely, role overload and role conflict as sources of stress and in turn excluded other role stressors such as role ambiguity, role stagnation, and role erosion from investigation. Second, the study examined one dimension of organizational commitment namely, affective commitment and excluded the other two dimensions namely, normative and continuance commitment. Third, the study relied heavily on the use of questionnaire to collect the required data.

Several lines of research suggest themselves. First, a comparison between managerial and non-managerial clerical staff in terms of perceptions of role overload and role conflict, as sources of stress would be of interest. Second, a comparison between managers of public and private sector commercial banks in terms of perceptions of role stress would also be worthwhile. Third, the study of the impact of demographic variables on the perceptions of role overload and role conflict as sources of stress is of interest. Finally, a study analyzing the relationships between demographic variables, role stressors, and job attitudes would be of interest.

\section{References}

Abdalla, I.A. (1991). Social support and gender responses to job stress in an Arab culture. Journal of Social Behavior and Personality, 6(7), 273-288. 
Addae, H.M., Parboteeah, K.P., \& Velinor, N. (2008). Role stressors and organizational commitment: Public sector employment in St Lucia. International Journal of Manpower, 29(6), 567-582.

Allen, N.J., \& Meyer, J.P. (1990). The measurement and antecedents of affective, continuance and normative commitment to the organization. Journal of Occupational Psychology, 63, 1-18.

Aziz, M. (2004). Role stress among Indian information technology sector. Women in Management Review, 19(7), 356-363.

Bacharach, S.B., Bamberger, P., \& Conley, S. (1991). Work-home conflict among nurses and engineers: Mediating the impact of role stress on burnout and satisfaction at work. Journal of Organizational Behavior, 12(1), 39-53.

Baron, R.M., \& Kenny, D.A. (1986). The moderator-mediator variable distinction in social psychological research: Conceptual, strategic, and statistical considerations. Journal of Personality and Social Psychology, 51(6), 1173-1182.

Bateman, T., \& Strasser S. (1984). A longitudinal analysis of the antecedents of organizational commitment. The Academy of Management Journal, 27(1), 95-112.

Bedeian, A.G., \& Armenakis, A.A. (1981). A path-analytical study of the consequences of role conflict and role ambiguity. The Academy of Management Journal, 24(2), 417-424.

Behrman, D.N., \& Perreault, W.D. (1984). A role stress model of the performance and satisfaction of industrial salespersons. The Journal of Marketing, 48(4), 9-21.

Boles, J., Madupalli, R., Rutherford, B., \& Wood, J.A. (2007). The relationship of facets of salesperson job satisfaction with affective organizational commitment. Journal of Business \& Industrial Marketing, 22(5), 311-321.

Carmeli A., \& Gefen, D. (2005). The relationship between work commitment models and employee withdrawal intentions. Journal of Managerial Psychology, 20(2), 63-86.

Clugston, M. (2000). The mediating effects of multidimensional commitment on job satisfaction and intent to leave. Journal of Organizational Behavior, 21(4), 477-486.

Cohen, A. (1996). On the discriminant validity of the Meyer and Allen measure of organizational commitment: How does it fit with the work commitment construct. Educational \& Psychological Measurement, 56(3), 494-593.

Coverman, S. (1989). Role overload, role conflict, and stress: Addressing consequences of multiple role demand. Social Forces, 67(4), 965-982.

Dixon, M.A., Cunningham, G.B., Sagas, M., Turner, B.A., \& Kent, A. (2005). Challenge is key: An investigation of affective organizational commitment in undergraduate interns. Journal of Education for Business, 80(3), 172-180.

Elangovan, A.R. (2001). Causal ordering of stress, satisfaction, and commitment, and intent to quit: A structural equations analysis. Leadership \& Organization Development Journal, 22(4), 159-165.

Falkenburg, K., \& Schyns, B. (2007). Work satisfaction, organizational commitment and withdrawal behaviors. Management Research News, 30(10), 708-723.

Farrell, D. \& Rusbult, C.E. (1981). Exchange variables as predictors of job satisfaction, job commitment, and turnover: The impact of rewards, costs, alternatives, and investments. Organizational Behavior and Human Performance, 27, 79-95.

Fineman, S., \& Payne, R. (1981). Role stress - A methodological trap? Journal of Occupational Behavior, 2(1), 51-64.

Fox, M.L., Dwyer, D.J., \& Ganster, D.C. (1993). Effects of stressful job demands and control on physiological and attitudinal outcomes in a hospital setting. The Academy of Management Journal, 36(2), 289-318.

Horne, J.C.V., \& Wachowicz, J.M. (1998). Fundamentals of Financial Management. (10th ed.). $\quad$ New Jersey: Prentice-Hall, Inc.

Ivancevich, J.M., \& Matteson, M.T. (1980). Stress and work: A managerial perspective. Glenview: Scott, Foresman and Company. 
Ivancevich, J.M., Olekalns, M., \& Matteson, M.T. (1997). Organizational behavior and management. Sydney: Irwin.

Iverson, R. D., \& Buttigieg, D.M. (1999). Affective, normative and continuance commitment: Can the 'right kind' of commitment be managed? Journal of Management Studies, 36(3), 307-333.

Jamal, M. (1990). Relationship of job stress and Type-A behavior to employees' job satisfaction, organizational commitment, psychosomatic health problems, and turnover motivation. Human Relations, 43, 727-738.

James, L.R., \& Brett J.M. (1984). Mediators, moderators, and tests of mediation. Journal of Applied Psychology, 69(2), 307-321.

Jenkins, M., \& Thomlinson, R.P. (1992). Organizational commitment and job satisfaction as predictors of employee turnover intentions. Management Research News, 15(10), 18-22.

Johnson, D.A., \& Weiss, D.J. (1971). Middle management, decision-making and job satisfaction. St Paul: Educational Research and Development Council.

Jones, E., Chonko, L., Rangarajan, D., \& Roberts, J. (2007). The role of overload on job attitudes, turnover intentions, and salesperson performance. Journal of Business Research, 60(7), 663-671.

Kahn, R.L., Wolfe, D., Quinn, R., Snoek, J., \& Rosenthal, R. (1964). Organizational stress: Studies in the role conflict and role ambiguity. New York: John Wiley.

Karsh, B., Booske, B.C., \& Sainfort, F. (2005). Job and organizational determinants of nursing home employee commitment, job satisfaction and intent to turnover. Ergonomics, 48(10), 1260-1281.

Kemery, E.R., Bedeian, A.G., Mossholder, K.W., \& Touliatos, J. (1985). Outcomes of role stress: A multisample constructive replication. Academy of Management Journal, 28, 363-375.

King, R.C., \& Sethi, V. (1997). The moderating effects of organizational commitment on burn-out in information systems professionals. European Journal of Information Systems, 6, 86-96.

Larson, L.L. (2004). Internal auditors and job stress. Managerial Auditing Journal, 19(9), 1119-1130.

Lee, T.W. (1988). How job dissatisfaction leads to employee turnover. Journal of Business and Psychology, 2(3), 263-271.

Lok, P., \& Crawford, J. (2001). Antecedents of organizational commitment and the mediating role of job satisfaction. Journal of Managerial Psychology, 16(8), 594-613.

Mathieu, J., \& Hamel, D. (1989). A cause model of the antecedents of organizational commitment among professionals and non-professionals. Journal of Vocational Behavior, 34, 229-317.

Mathieu, J.E., \& Zajac, D. (1990). A review and meta-analysis of the antecedents, correlates, and consequences of organizational commitment. Psychological Bulletin, 108, 171-194.

McKinnon, P.K. (2008). Introduction to statistical mediation analysis. New York: Taylor and Francis Group.

Meyer, J.P., Becker, T.E., \& Vanderberghe, C. (2004). Employee commitment and motivation: A conceptual analysis and integrative model. Journal of Applied Psychology, 89(6), 991-1007.

Meyer, J.P., Stanley, D.J., Herscovitch, L., \& Topolnytsky, L. (2002). Affective, continuance, and normative commitment to organization: A meta-analysis of antecedents, correlates, and consequences. Journal of Vocational Behavior, 61, 20-52.

Montgomery, D.C., Blodgett, J.G., \& Barnes, J.H. (1996). A model of financial securities salespersons' job stress. The Journal of Services Marketing, 10(3), 21-38.

Morris, J.H., and Sherman, J.D. (1981). Generalizability of an organizational commitment model. Academy of Management Journal, 24, 512-526

Morrow, P.C. (1993). The theory and measurement of work commitment. Greenwich: JAI Press Inc.

Mowday, R.T., Richard, M.S., \& Porter, L.W. (1979). The measurement of organizational commitment. Journal of Vocational Behavior, 14 (2), 224-247.

Netemeyer, R.G., Burton, S., \& Johnson, M.W. (1995). A nested comparison of four models of the consequences of role perception variables. Organizational Behavior and Human Decision Processes, 61(1), 77-93.

Oliver, R.L., \& Brief, A.P. (1977). Determinants and consequences of role conflict and ambiguity among retail sales rnanagers. Journal of Retailing, 53 (4), 47-58. 
Parasuraman, S., \& Alutto, J.A. (1984). Sources and outcomes of stress in organizational settings: Toward the development of a structural model. Academy of Management Journal, 27(2), 330-350.

Pareek, U. (1993). Making organizational roles effective. New Delhi: Tata McGraw Hill.

Porter, L.W., Steers, R.M., Mowday, R.T., \& Boulian, P.V. (1974). Organizational commitment, job satisfaction, and turnover among psychiatric technicians. Journal of Applied Psychology, 59, 603-609.

Preacher, K.J., \& Hayes A.F. (2004). SPSS and SAS procedures for estimating indirect effects in simple mediation models. Behavior Research Methods, Instruments, \& Computers, 36(4), 717-731.

Rizzo, J.R., House, R.J., \& Lirtzman, S.I. (1970). Role conflict and ambiguity in complex organizations. Administrative Science Quarterly, 15(2), 150-163.

Ruyter, K., Wetzels, M., \& Feinberg, R. (2001). Role Stress in call centers: Its effect on employee performance and satisfaction. Journal of Interactive Marketing, 15(2), 23-35.

Schaubroeck, J., Cotton, J.L., \& Jennings, K.R. (1989). Antecedents and consequences of role stress: A covariance structure analysis. Journal of Organizational Behavior, 10 (1), 35-58.

Shrout, P.E., \& Bolger, N. (2002). Mediation in experimental and nonexperimental studies: New procedures and recommendations. Psychological Methods, 7(4), 422-445.

Singh, J. (1998). Striking a balance in boundary-spanning positions: An investigation of some unconventional influences of role stressors and job characteristics on job outcomes of salespeople. The Journal of Marketing, 62(3), 69-86.

Singh, J., Goolsby, J.R., \& Rhoads, G.K. (1994). Behavioral and psychological consequences of boundary spanning burnout for customer service representatives. Journal of Marketing Research, 31(4), 558-569.

Spector, P.E. (1985). Measurement of human service staff satisfaction: Development of the job satisfaction survey. American Journal of Community Psychology, 13(6), 693-713.

Steers, R.M. (1977). Antecedents and outcomes of organizational commitment. Administrative Science Quarterly, 22(1), 46-56.

Steers, R.M., \& Mowday, R.T. (1981). Employee turnover and post-decision accommodation processes. Research in Organizational Behavior, 3, 235-281.

Stevens, J.M., Beyer, J.M., \& Trice, H.M. (1978). Assessing personal, role, and organizational predictors of managerial commitment. The Academy of Management Journal, 21(3), 380-396.

Suliman, A.M.T. (2002). Is it really a mediating construct? The mediating role of organizational commitment in work climate-performance relationship. Journal of Management Development, 21(3), 170-183.

Tompson, H., \& Werner, J. (1997). The impact of role conflict/facilitation on core and discretionary behaviors: Testing a mediating model. Journal of Management, 23(4), 583-601.

Udo, G.J., Guimaraes, T., \& Igbaria, M. (1997). An investigation of the antecedents of turnover intention for manufacturing plant managers. International Journal of Operations \& Production Management, 17(9), 912-930.

Vandewalle, D., Dyne, L., \& Kostova, T. (1995). Psychological ownership: An empirical examination of its consequences. Group and Organization Management, 20(2), 210-226.

Williams, L.J., \& Hazer, J.T. (1986). Antecedents and consequences of satisfaction and commitment in turnover models: A re-analysis using latent variable structure equation models. Journal of Applied Psychology, 71(2), 219-231.

Yousef, D.A. (2002a). Job satisfaction as a mediator of the relationship between role stressors and organizational commitment. Journal of Managerial Psychology, 17(4), 250-266.

Yousef, D.A. (2002b). Job satisfaction as a mediator of the relationship between job stressors and affective, continuance, and normative commitment: A path analytical approach. International Journal of Stress Management, 9(2), 99-112.

Yperen, N.W., Berg, A.E., \& Willering, M.C. (1999). Towards a better understanding of the link between participation in decision-making and organizational citizenship behavior: A multilevel analysis. Journal of Occupational and Organizational Psychology, 72, 377-391. 
Table 1. The Main Characteristics of the Sample $(\mathrm{N}=151)$

\begin{tabular}{|l|c|c|}
\hline Characteristics & Frequency & Percent \\
\hline Gender & 141 & \\
Male & 10 & $73 \%$ \\
Female & & \\
\hline Age & 22 & $15 \%$ \\
Less than 35 years & 113 & $75 \%$ \\
$35-45$ years & 16 & $10 \%$ \\
More than 45 years & & \\
\hline Education Level & 21 & $14 \%$ \\
Bachelor: & 04 & $3 \%$ \\
14 years degree & & \\
$\quad 16$ years degree & 121 & $30 \%$ \\
Master: & 05 & $47 \%$ \\
16 years degree & & $42 \%$ \\
18 years degree & 71 & $11 \%$ \\
\hline Tenure as Branch Manager & 63 & \\
Less than 5 years & 17 & \\
5-10 years & & \\
More than 11 years & & \\
\hline
\end{tabular}

Table 2. Descriptive Statistics of the Main Variables

\begin{tabular}{|l|c|c|c|c|c|}
\hline & N & Minimum & Maximum & Mean & $\begin{array}{c}\text { Std. } \\
\text { Deviation }\end{array}$ \\
\hline RO & 151 & 1.33 & 4.67 & 3.38 & .885 \\
\hline RC & 151 & 1.50 & 4.50 & 3.26 & .774 \\
\hline JS & 151 & 1.45 & 4.25 & 2.62 & 1.012 \\
\hline AC & 151 & 1.44 & 4.33 & 2.42 & .750 \\
\hline
\end{tabular}

Table 3. The Results of the Bivariate \& Partial Correlation Tests

\begin{tabular}{|c|c|c|c|c|}
\hline Variables & RO & RC & JS & AC \\
\hline RO & 1 & & & \\
\hline RC & $.629^{* *}$ & 1 & & \\
\hline JS & $-.417^{* *}$ & $-.410^{* *}$ & 1 & \\
\hline AC & $-.411^{* *}$ & $-.366^{* *}$ & $.539^{* *}$ & 1 \\
\hline
\end{tabular}

Note. ${ }^{* *} p<.01 . R O=$ Role Overload; RC = Role Conflict; JS = Job Satisfaction; AC = Affective Commitment.

\begin{tabular}{|c|c|c|c|}
\hline \multicolumn{4}{|c|}{ Partial Correlation Controlled for JS } \\
\hline Variables & RO & RC & AC \\
\hline RO & 1 & & \\
\hline RC & $.553^{* *}$ & 1 & 1 \\
\hline AC & $-.244^{* *}$ & $-.189^{*}$ & \\
\hline
\end{tabular}

Note. ${ }^{*} p<.05 .{ }^{* *} p<.01$. 
Table 4. Results of the Mediated Regression Approach for JS (RO-AC)

\begin{tabular}{|c|c|c|c|c|c|c|c|c|}
\hline No. & DV & IV & Beta & T & Sig. T & F & Sig. F & $\begin{array}{c}\text { Adjusted } \\
\mathbf{R}^{2}\end{array}$ \\
\hline $\mathbf{1}$ & AC & RO & -.411 & -5.510 & .000 & 30.360 & .000 & 0.164 \\
\hline $\mathbf{2}$ & JS & RO & -.417 & -5.600 & .000 & 31.360 & .000 & 0.168 \\
\hline $\mathbf{3}$ & AC & JS & .445 & 6.017 & .000 & 36.871 & .000 & 0.324 \\
& & RO & -.226 & -3.059 & .003 & & & \\
\hline
\end{tabular}

Table 5. Results of the Mediated Regression Approach for JS (RC-AC)

\begin{tabular}{|c|c|c|c|c|c|c|c|c|}
\hline No. & DV & IV & Beta & T & Sig. T & F & Sig. F & $\begin{array}{c}\text { Adjusted } \\
\mathbf{R}^{\mathbf{2}}\end{array}$ \\
\hline $\mathbf{1}$ & AC & RC & -.366 & -4.803 & .000 & 23.067 & .000 & 0.128 \\
\hline $\mathbf{2}$ & JS & RC & -.410 & -5.488 & .000 & 30.115 & .000 & 0.163 \\
\hline $\mathbf{3}$ & AC & JS & .467 & 6.268 & .000 & 34.138 & .000 & 0.306 \\
& & RC & -.175 & -2.341 & .021 & & & \\
\hline
\end{tabular}

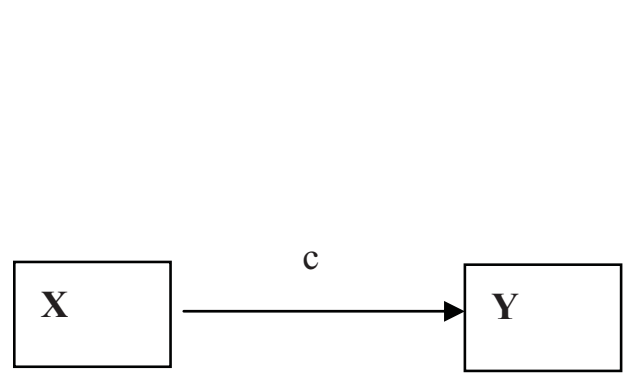

Panel A

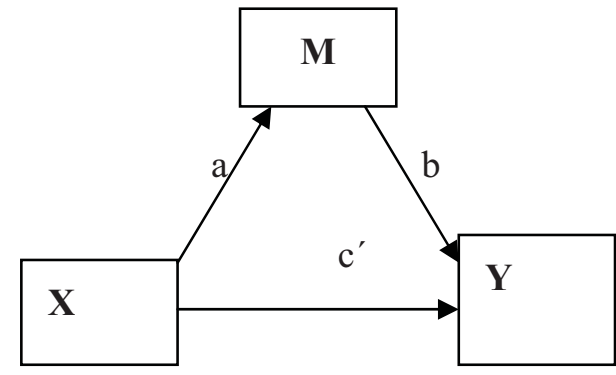

Panel B

Figure 1. Panel A: Illustration of Total Effect of X on Y

Panel B: Illustration of Mediated Effect of X on $\mathrm{Y}$

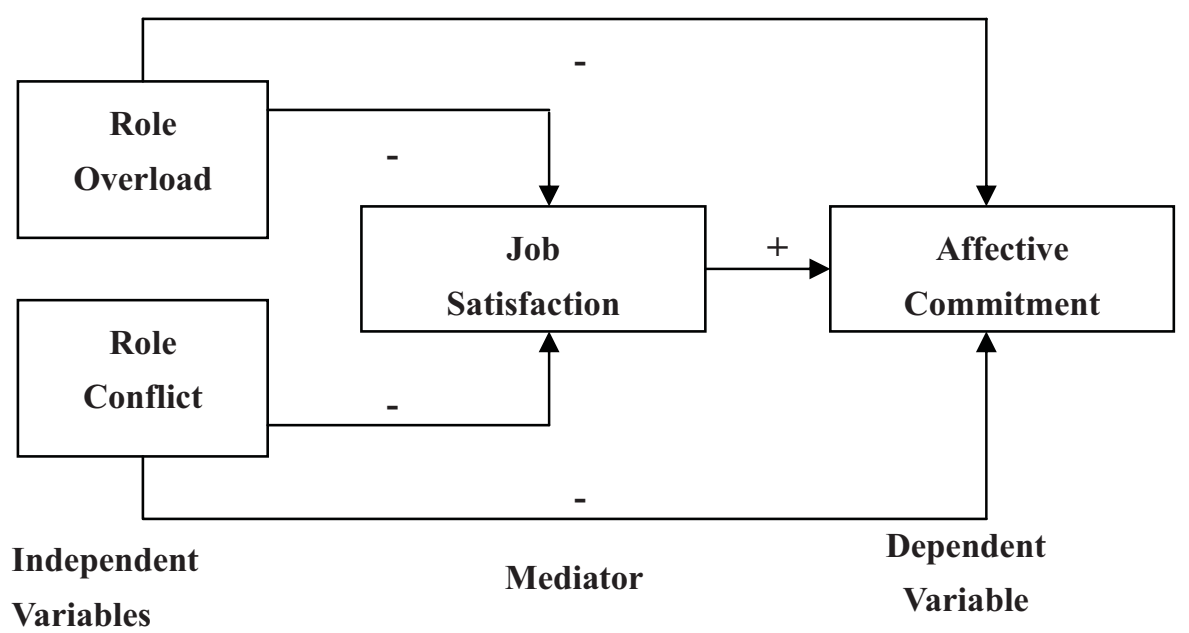

Figure 2. The Figure Describes the Mediating Effects of job Satisfaction on Role Stressors and Affective Commitment. 


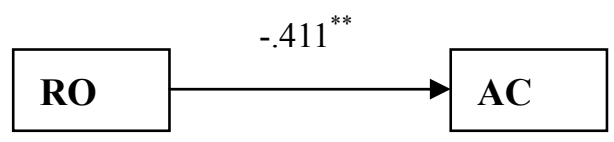

Panel A

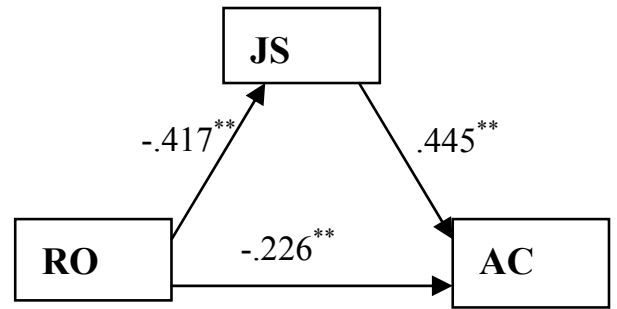

Panel B

Figure 3. The Estimated Single Mediator Model JS (RO-AC). The Numbers in the Figure Represent Standardized Regression Coefficients. ${ }^{* *} \mathrm{p}<.01$

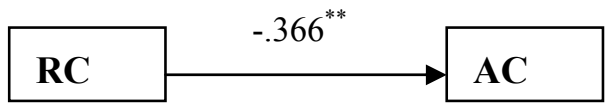

Panel A

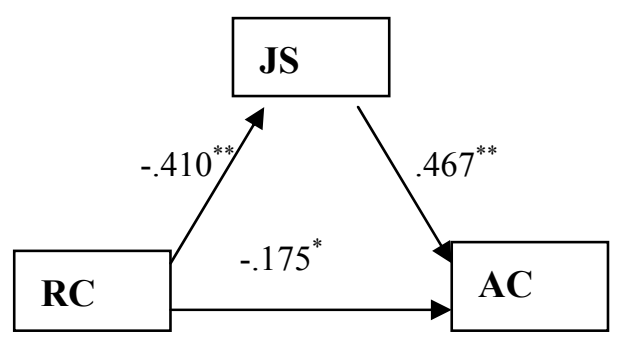

Panel B

Figure 4. The Estimated Single Mediator Model JS (RC-AC). The Numbers in the Figure Represent Standardized Regression Coefficients. ${ }^{*} \mathrm{p}<.05 .{ }^{* *} \mathrm{p}<.01$. 